\title{
Systematic review of interventions to increase recruitment and retention of black, minority and ethnic patients into randomised controlled trials
}

\author{
Gulnaz lqbal ${ }^{1 *}$, Janet Dunn', Margaret Thorogood ${ }^{1,2}$ \\ From 2nd Clinical Trials Methodology Conference: Methodology Matters \\ Edinburgh, UK. 18-19 November 2013
}

Recruitment into cancer trials has been an area of concern for numerous years. In 2000 the NHS plan sought to double the number of patients entering cancer trials within 3 years. This was achieved through the creation of the National Cancer Research Network in 2001. By 2004 , approximately $10.9 \%$ of all cancer patients were entered into a trial. However, recruitment of Black, Minority and Ethnic (BME) patients into clinical trials has been reported to be under-represented compared to the split of ethnicity both within the reported incidence of disease and the reported total population. Mason found a two-fold under representation of South Asians within breast cancer trials (Mason et al, 2003).

In the USA, a significant under-representation of Hispanics, Blacks and Asians was found when comparing ethnic proportions recruited within oncology trials with existing cancer cases (Murthy et al, 2004). The underrepresentation of any patient group within a clinical trial, specifically an ethnic one, can bias trial results, and subsequent extrapolation into the general population.

A systematic literature review of interventions to improve the recruitment and retention of minority patients into clinical trials was conducted. The search intended to capture literature pre- and post the Race Relations Act Amendment (2000) and the USA National Institute of Health Revitalisation Act (1993).

Preliminary results of the review have revealed a paucity of published evidence from the UK, with the majority of the articles meeting the inclusion criteria originating from the USA. Final results will be presented.

'University of Warwick, Coventry, UK

Full list of author information is available at the end of the article

\section{Authors' details}

${ }^{1}$ University of Warwick, Coventry, UK. ${ }^{2}$ University of the Witwatersrand, Johannesburg, South Africa.

Published: 29 November 2013

doi:10.1186/1745-6215-14-S1-P83

Cite this article as: lqbal et al: Systematic review of interventions to increase recruitment and retention of black, minority and ethnic patients into randomised controlled trials. Trials 2013 14(Suppl 1):P83.

Submit your next manuscript to BioMed Central and take full advantage of:

- Convenient online submission

- Thorough peer review

- No space constraints or color figure charges

- Immediate publication on acceptance

- Inclusion in PubMed, CAS, Scopus and Google Scholar

- Research which is freely available for redistribution 